\title{
Nada Grošelj
}

University of Ljubljana

Faculty of Arts, English Department

\section{Belletristic Translation into English: What Price the Same Order of Words?}

\author{
Summary
}

The order of clause constituents in Slovene is largely guided by functional sentence perspective, while its English counterpart is grammar-based and much less flexible. Therefore the English translation of a Slovene clause often displays a different order of constituents. In poetry, however, the position assigned to an entity, action, or concept within a line of verse contributes to the overall meaning, text pattern, and poetic effect. Accordingly, efforts are made to preserve the same order of participants in translation, which often results in the assignment of a new syntactic role to the participant and the restructuring of the entire clause. This paper discusses the most frequent types of restructuring employed in the English translations of select poems by the contemporary Slovene poet Dane Zajc.

Key words: linguistics, translation studies, contrastive analysis, word order, functional sentence perspective

\section{Vprašanje besednega reda pri leposlovnem prevajanju $v$ angleščino}

Povzetek

Zaporedje stavčnih členov se v slovenščini večinoma ravna po členitvi po aktualnosti, medtem ko je v angleščini slovnično določeno in temu ustrezno veliko manj prožno. Zato se mora pri prevajanju iz slovenščine $\mathrm{v}$ angleščino pogosto spremeniti. Težave pa nastopijo pri prevajanju poezije, saj je za pomen, vzorec in splošni pesniški učinek besedila pomemben prav položaj, ki ga v verzu zavzemajo posamezni pojmi. Zato si prevajalci prizadevajo ohraniti izvirno mesto udeležencev, če pa je to zaradi njihovih skladenjskih vlog nezdružljivo z angleškimi slovničnimi pravili, jim pogosto dodelijo nove vloge in spremenijo zgradbo stavka. $V$ prispevku obravnavam najpogostejše tipe tovrstnih skladenjskih sprememb $\mathrm{v}$ angleških prevodih izbranih pesmi sodobnega slovenskega pesnika Daneta Zajca.

Ključne besede: jezikoslovje, prevodoslovje, protistavna analiza, besedni red, členitev po aktualnosti 


\section{Belletristic Translation into English: What Price the Same Order of Words?}

\section{Introduction}

The term "word order" refers, strictly speaking, only to the linear sequence of individual words. However, it is generally used also to refer to the sequence of clause elements (Davis $1989,15)$, and it is this latter meaning that is the focus of the present discussion. In Slovene, a language with rich morphology, where the relations between clause elements are made sufficiently clear by the inflections of the words, the sequence of these elements is largely "free". Almost the only clause constituents whose position in the clause is determined grammatically are clitics (e.g. the short unstressed forms of personal and reflexive pronouns, certain forms of the verb biti, "be", and some particles) and the sequence of co-occurring clitics. There are also a few other tendencies and restrictions, for example the obligatory sequence "subject - predicator - object" in the case of homonymous forms, where it serves to avoid ambiguity (Toporišič 2000, 676). With these exceptions, the sequence of clause elements depends on functional sentence perspective (FSP), beginning with given or less important information and proceeding towards the most salient part of the message.

In English, by contrast, the relations among the clause elements are not signalled by inflections. This role is accordingly fulfilled by word order, with syntactic categories following each other in a more or less prescribed sequence. The more central an element is, the more fixed its position, whereas peripheral elements are more mobile. After the predicator, the subject is the least mobile element, followed by the object and by the subject or object complement. The most peripheral and mobile category are adverbials, with the types of adverbial again differing in their degrees of centrality and therefore freedom (Quirk et al. 1992, 51). The English translation of a Slovene clause will thus often display a different order of constituents, e.g. the move of a non-initial subject into initial position. In poetry, however, the position assigned to an entity, action, or concept within a line of verse has important implications for the overall meaning, text pattern, and poetic effect. Accordingly, efforts are made to preserve the same order of participants in translation, which often results in the assignment of new syntactic roles and in the restructuring of the entire clause, as in passivisation.

This paper discusses such instances of clause restructuring in regard to the contemporary Slovene poet Dane Zajc and the English translations of his poetry, focusing on the structures most frequently undergoing changes and on the most frequent types of restructuring. The examined material covers a group of eighteen poems which exists in two different English translations; only ten poems, however, are referred to in the paper, since every structure is illustrated by one example only. The poems discussed are "Ujeti volk" (originally published in 1958), "Veliki črni bik" (1958), "Vse ptice" (1958), "Kralj" (1961), "Za vse boš plačal" 
(1963), “Tihi škrebetavec” (1968), “Ubijalci kač” (1968), "Za prevali” (1979), "Belo” (1984), and "Krokar" (1998). The texts of the first nine are taken from Zajc (1990), and the last from Zajc (1998).

An examination of the original texts by Zajc and their translations reveals that three types of Slovene constituent ordering are most commonly avoided in English as marked, emphatic, or even impossible, with restructurings being preferred instead. These three types are the following:

1. The Slovene subject occupies the final position in the clause, or is at least placed after the predicator.

2. The Slovene object occupies the initial position, or is at least placed in front of the predicator.

3. The Slovene adverbial adjunct occupies a position which does not correspond to the position usual for this semantic type of adjunct in English.

\section{Discussion of examples}

\subsection{The Slovene subject occupies the final position in the clause, or is at least placed after the predicator}

The non-initial Slovene subjects in my corpus which are assigned other syntactic roles in translation for the purpose of maintaining the same position are rendered by a wide range of restructurings: as the notional subjects of there-clauses (existential and presentational), as agentive adjuncts in passive structures, objects (rephrased as such by the use of epistemic converses), discontinuous noun phrases, appositive phrases, and supplementive clauses. In two cases, the original ordering and syntactic structure are preserved, but sound so uncongenial to English that they actually invite a different syntactic interpretation.

\subsubsection{Existential clause: "Za prevali", v. 12}

\begin{tabular}{|l|l|}
\hline Za prevali ni sledi. & Beyond the mountain pass there is no trace. \\
\end{tabular}

(Literally: "Beyond the mountain passes are no tracks.")

The adjunct of place is a typical setting, which is naturally placed in clause-initial position in FSPdominated languages like Slovene. The most important item of information, on the other hand, is represented by the entity whose existence is negated - the subject - and accordingly placed at the end. From the perspective of the poem, it is vital that the initial position of the adjunct - and consequently the final position of the subject - should be preserved, since the same prepositional phrase recurs at line beginnings throughout the text, thus creating an anaphora.

Perčič and Peet 1988. 
This requirement is met in both translations, although at the cost of acquiring a slightly marked stylistic flavour. While English space adjuncts, particularly those expressing position (setting) like the above, often do appear in initial position (Quirk et al. 1992, 521), they still favour the final position, "irrespective of grammatical function or semantic role" (ibid.).

Another feature contributing to the stylistic effect is the structure of the clause. The alternative translation employs the same structure as the original, i.e. subject-predicator inversion accompanying the preposing of the adjunct: "Beyond the passes are no tracks." 2 This structure is common in English when a predication adjunct (the category includes obligatory adjuncts such as the above) is in initial position (op. cit., 522). Nevertheless, inversion as such is still slightly marked. According to Quirk et al., some instances of preposing-cum-inversion, including an example with a preposed locative adjunct parallel to the above ("There at the summit stood the castle in all its medieval splendour"), are admittedly "less rhetorically unnatural" than others, but they are still "less common in ordinary speech" (op. cit., 1380).

To fully assess the markedness of the structure, the type of the postponed subject noun phrase needs to be considered as well. If the subject phrase is indefinite (this may be effected through premodification by an indefinite pronoun, such as "no" in this case) and the predicator is realised by the verb "be", corpus research has revealed a preference for the use of the existential structure with the grammatical subject "there" over the basic clause structure with a preposed locative adjunct and subject-predicator inversion (op. cit., 1410). The existential clause structure of the translation given in the table is thus more idiomatic than the basic structure of the alternative translation.

\subsubsection{Presentational clause: “Krali”, vv. 6-7}

\begin{tabular}{|l|l|}
$\begin{array}{l}\text { [Sestavljen iz starih razpadlih verig, ...] } \\
\text { je vstal pred mano kralj, } \\
\text { kronan s krono iz temnih misli. }\end{array}$ & $\begin{array}{l}\text { [Made up of old broken chains ...] } \\
\text { there rose before me a king } \\
\text { crowned with a crown of dark } \\
\text { thoughts. }\end{array}$ \\
\hline
\end{tabular}

(Literally: "[...] rose before me a king / crowned with a crown of dark thoughts.")

Since the sentence expresses the appearance of an entity on the scene, this entity represents the most important item of information and is accordingly placed in final position in Slovene. The translation given above employs the presentational structure, thus re-creating the original by placing the notional subject last and at the same time satisfying the requirements of the canonical English word order (with the initial grammatical subject). It should be noted, though, that the presentational structure - a there-clause with a verb other than "be" - is judged to be more literary by Quirk et al. than a there-clause with "be", so that it "is equivalent in effect and style to subject-verb inversion after an initial adverbial" $(1992,1408)$.

\footnotetext{
Johnson Debeljak 2000.

3 MacKinnon 1965.
} 
The other translation, conversely, employs a discontinuous noun phrase, putting the headword "king" before the predicator but retaining the participial structure in final position: "[Made of old disintegrating chains, ...] / - a king stood before me, / crowned with a crown of dark thoughts." ${ }^{\prime 4}$ As a result, the connection between the original headword and the postmodifying participial clause is weakened, since the clause standing on its own may also be interpreted as a supplementive (adverbial) clause expressing an accompanying circumstance.

\subsubsection{Passivisation -> agentive adjunct role: "Ubijalci kač", vv. 3-5}

\begin{tabular}{|l|l|}
\hline $\begin{array}{l}\text { Ampak to delajo samo tisti, } \\
\text { ki imajo radi sebe }\end{array}$ & $\begin{array}{l}\text { But this is done only by those } \\
\text { who are fond of themselves }\end{array}$ \\
in si zelo zaupajo. & $\underline{\text { and very self-confident. }}$
\end{tabular}

(Literally: "But this do only those / who like themselves / and have much confidence.")

The other translation preserves the active voice and accordingly employs the canonical English word order: "But only those who like themselves / and have much confidence / do this."'

\subsubsection{Object role: "Vse ptice", wv. 26-7}

\begin{tabular}{|c|c|}
\hline $\begin{array}{l}\text { [In zbal sem se, } \\
\text { da mi bo [vran] neko noč } \\
\text { skoz temne sanje } \\
\text { razklal lobanjo } \\
\text { in da bo iskal z blaznim kljunom,] } \\
\text { če se v gnezdu mojih misli } \\
\text { ne skrivajo pojoče ptice. }\end{array}$ & $\begin{array}{l}\text { [And then I felt afraid } \\
\text { that perhaps some night } \\
\text { through dreams of darkness } \\
\text { he [a raven] would split my skull } \\
\text { and probe with his maniac beak] } \\
\text { to see if the nest of my thoughts } \\
\text { sheltered any hidden songbirds. }\end{array}$ \\
\hline
\end{tabular}

(Literally: "[And I felt afraid / that he [a raven] would one night / through my dark dreams / split open my skull / and that he would search with his crazy beak] / if in the nest of my thoughts / were hiding any songbirds.")

The Slovene ordering reflects the FSP: the setting ("in the nest of my thoughts") is followed by the predicator and finally by the subject, the latter representing the most important item of information. The final position of the original subject, the participant "songbirds", is preserved in both translations, but only by means of substantial restructurings. The alternative translation assigns this participant the role of a prepositional object, but the sentence structure is so compressed and altered that it does not allow comparison with the original: "[And I was afraid / that one night / through my dark dreams / he [a raven] would split open my skull / and with his crazy beak] / search in the nest of my thoughts / for any songbirds hidden there." ${ }^{8}$

\footnotetext{
Taufer and Scammell 1970.

Taufer and Scammell 1970.

Biggins 1994.

7 MacKinnon 1965.

8 Taufer and Scammell 1982.
} 
The overall structure of the translation given in the table, on the other hand, remains closer to the original, except for the two lines under discussion, where the Slovene subject is assigned the object role by the use of a converse ("hide" vs. "shelter"). The original adverbial adjunct of place accordingly assumes the role of the subject. In English translations from Slovene, this process is a commonplace means of preserving the original ordering of participants and employing the unmarked English word order at the same time (Klinar 1996, 277).

\subsubsection{Discontinuous noun phrase: “Ujeti volk”, vv. 26-7}

\begin{tabular}{|l|l|l|}
\hline $\begin{array}{l}\text { [Zakaj si zatulil, volk, } \\
\text { kot da bi zatulila zemlja, } \\
\text { ki jo pritiska gora skal? }\end{array}$ & $\begin{array}{l}\text { [Why do you howl, wolf, } \\
\text { as the earth howls, } \\
\text { when crushed by a mountain of } \\
\text { rocks? }\end{array}$ & $\begin{array}{l}\text { [Why did you howl, wolf, } \\
\text { as the earth howls, }\end{array}$ \\
$\begin{array}{l}\text { when crushed by a mountain of } \\
\text { rocks? }\end{array}$ \\
\hline
\end{tabular}

(Literally: "[Why did you howl, wolf,] / as if had howled the earth, / on which presses a mountain of rocks?")

Both translations transform the original relative clause into a separate sentence element, namely into an adverbial adjunct of time, or possibly of contingency. ${ }^{11}$ The most likely reason is the requirement of the unmarked English word order that the subject precede the predicator, coupled with the end-weight principle (according to which longer and more complex elements are placed towards the end of the clause) and presumably with the translators' desire to preserve the original, final position of the subordinate clause. If the relative clause was incorporated in the subject and therefore preceded the predicator, both the end-weight principle and the original linear order would be violated. One solution is the use of a discontinuous noun phrase, where the clause could still be understood as a postmodifier: "as the earth howls, which is crushed ..." This discontinuous phrase, however, is subjected to yet further changes in both translations, the postmodifier being transformed into an adverbial adjunct.

\subsubsection{Apposition: "Krokar", wv. 31-4}

Ko leti nizko, se mu na perutih lesketa črno kljubovanje kraljestva skrivnosti.
When he flies low, there is a glimmering upon his feathers the black defiance of the realm of mystery. ${ }^{12}$

(Literally: "When he flies low, / on his wings glimmers / a black defiance of the kingdom of / mystery.")

9 Johnson Debeljak 1997.

10 Kravanja 2000.

11 "The meaning of several subordinators that primarily express time, place, or condition may be neutralized in certain contexts to convey a more abstract notion of recurrent or habitual contingency: when, ..." (Quirk et al. 1992, 1086).

12 Johnson Debeljak 1997. 
The alternative translation adopts the original structure: "When he flies low / on his wings / glimmers / a black defiance / of the kingdom of / mystery." ${ }^{33}$ Subject-predicator inversion accompanying the preposing of a locative adverbial adjunct is quite common in English, as explained above; nevertheless, the structure is more marked in English than in Slovene. This may be the reason why the translation given in the table has recourse to substantial restructuring, resulting in "discontinuous apposition" (for the term cf. Quirk et al. 1992, 1302). The original subject is rendered as a postponed appositive phrase, separated from the first appositive ("a glimmering"), which precedes the predicator in keeping with the canonical English word order.

\subsubsection{Supplementive clause: "Tihi škrebetavec", wv. 4-9}



(Literally: "The white bone, buried in ashes, / planes with its black legs, / gentler than thistledown, / the quiet planer / with an unreadable purpose / in its speckled eyes.")

The subject of the English sentence given in the table is "the silent grindbeetle" from the first stanza of the poem: "All night long the silent grindbeetle / smooths with its six legs / a white bone." The final noun phrase - the Slovene subject - is thus best analysed as a supplementive clause. The other translation preserves the final position of this participant as well, which it achieves by passivisation. In contrast to the usual process, however, the participant is not assigned the role of the agentive adjunct but that of a postmodifier in the noun phrase realising this adjunct: "Buried in ash, the white bone / is planed by the black legs, / gentler than thistledown, / of the quiet planer, / with an unreadable intention / in its speckled eyes." 15

\subsubsection{Possibility of a different syntactic interpretation:}

\subsubsection{1 "Belo", v. 9}

[in vemo: pot je uročena pot je napačna] zavožena je pot [and we know: our path is bewitched our path is mistaken] is lost our path ${ }^{16}$

(Literally: "[and we know: the way is bewitched / the way is wrong] gone to seed is the way.")

13 Kravanja 2000.

14 Mackinnon 1980.

15 [Taufer and Scammell] 1997.

16 Johnson Debeljak 1997. 
The problematic part is the last clause, where the subject complement is originally placed first and the subject last. The alternative translation simply omits the whole clause: "[we know: the path is determined / the path is mistaken]." ${ }^{17}$ The translation quoted in the table, on the other hand, preserves the original ordering of predicate and subject. What it does not preserve is the ordering within the predicate, namely the sequence of the subject complement and copula, although the preposing of a subject complement accompanied by subject-predicator inversion is possible in English. Instead, it introduces the sequence "copula - subject complement - subject", which is ungrammatical. Attempting to impose an acceptable interpretation on the structure, a reader would probably take the entire predicate, "is lost", as an instance of asyndetic coordination with the predicate of the preceding clause, while the final "our path" would be understood as an expressive repetition of the subject already mentioned.

\subsubsection{2 "Za prevali”, vv. 8-9}

Za prevali se hitro poslavljajo prijatelji, ljubimci, znanci.

Beyond the mountain pass bid speedy farewell friends, lovers, acquaintances. ${ }^{18}$

(Literally: "Beyond the mountain passes speedily bid farewell / friends, lovers, acquaintances.")

The translation given in the table preserves the original order, but the result is so heavily marked that it invites an alternative interpretation. The form of the verb might be understood as the imperative and the noun phrase following the predicator construed as an indirect object, although the expression "bid farewell" is more commonly followed by a prepositional phrase with "to". The other translation employs the canonical word order: "Beyond the passes, friends and lovers, / acquaintances bid farewell fast." 19

\subsection{The Slovene object occupies the initial position, or is at least placed in front of the predicator}

Object preposing without inversion is frequently employed in English. The object may be thematic, that is, of relatively low communicative value, for example because it is known from the preceding context and provides direct linkage with it. It may also be rhematic, which means that it conveys important new information. A rhematic preposed object is always stylistically marked, having either the flavour of impromptu informal speech or of mannered rhetoric (Quirk et al. 1992, 1377, 1378). Even a thematic preposed object, however, is felt to be more emphatic in English than in a language with a more flexible word order. The English structure which fully corresponds to the perfectly neutral effect of a preposed thematic object in a Slavic language or in German is the canonical English ordering of predicator - object (Firbas 1992, 126) or one of the information-packaging constructions, such as the identifying clause "This is 
the book he gave me for Christmas" (Kirkwood 1970, 104). Since an English preposed object is thus always more emphatic than the same structure in Slovene, translators often preserve the original order of participants by altering their syntactic roles.

The Slovene examples addressed in this paper are rephrased in one translation in such a way that the participant retains the same position but is assigned a different syntactic role, while the other translation preserves the original syntactic structure and thus moves the object after the predicator. In the first two examples, the original order of participants is effected through passivisation, the non-final object becoming the passive subject when in initial position or an adverbial adjunct when non-initial. In the third example, the initial object is made the subject by the use of an epistemic converse. In the fourth, the initial object is preserved in the same position but is more likely to be interpreted as a conjunct, i.e. an adverbial element.

\subsubsection{Passivisation -> subject role: "Thi škrebetavec", vv. 4-9}

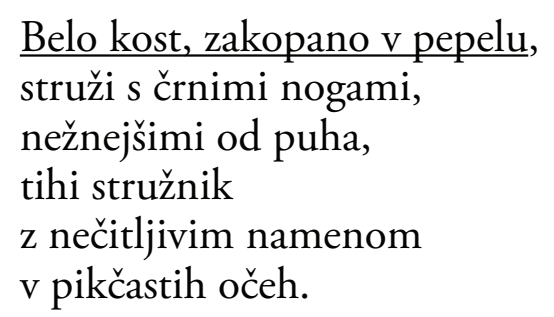

Buried in ash, the white bone is planed by the black legs, gentler than thistledown, of the quiet planer, with an unreadable intention in its speckled eyes. ${ }^{20}$

(Literally: "The white bone, buried in ashes, / planes with its black legs, / gentler than thistledown, / the quiet planer / with an unreadable purpose / in its speckled eyes.")

The alternative translation preserves the active voice and the object role of the participant, with the result that the latter is moved after the predicator: "Rubbing smooth a white bone / buried in ashes / with its black legs / softer than down / a silent grinding-tool / with inscrutable purpose / in its dots of eyes." 21

\subsubsection{Passivisation -> adverbial adjunct role: "Thi škrebetavec", vv. 26-7}

Vso noč gladi s šesterimi nogami

belo kost tihi škrebetavec.
All night the six legs are rubbed on the white bone by the quiet chaferbug. ${ }^{22}$

(Literally: "All night smooths with its six legs / the white bone the quiet chaferbug.")

This example represents an exception in the group, since the Slovene object is already postverbal. Nevertheless, its placement would be marked in English because it appears in non-

20 [Taufer and Scammell] 1997.

21 MacKinnon 1980.

22 [Taufer and Scammell] 1997 
final position, before the subject. In its attempt to reflect the original structure as closely as possible, the translation quoted above redistributes the syntactic roles completely, but the effect is still stylistically marked because the restructuring itself is rather unusual. Moreover, the sequence of the adverbial adjuncts employed is not the most canonical version; according to Quirk et al., the most common sequence of final adjuncts is that of "process [including the adverbial adjunct of agent] - space" $(1992,565)$, as in "The royal wedding was seen by millions on television" (op. cit., 559). Thus the restructuring still results in a marked ordering of constituents. The other translation retains the active structure, accordingly placing the object in final position: "All night long with its six legs / the silent grindbeetle is smoothing a white bone." 23

\subsubsection{Subject role: "Veliki črni bik”, vv. 22-3}

[Nobeden ne sliši tvoje samote.]

Nikogar ne napojiš

s črno krvjo svojega glasu.
[Nobody hears your loneliness.]

Nobody drinks

the black blood of your voice. ${ }^{24}$

(Literally: "[No one hears your solitude.] / Nobody do you slake / with the black blood of your voice.")

The Slovene text is more emphatic than the English versions because the initial object actually represents new information, so that its most natural place in Slovene would be at the end. In this particular case it is important to preserve the original sequence of participants, because a negative pronoun, nobeden, appears in initial position in the preceding line as well (this time in the role of the subject), so that lines 21 and 22-3 constitute a parallelism. The same figure is achieved by the solution quoted above but lost in the other translation: "[No one hears your solitude.] / You quench no one's thirst / with your black and bloodied voice."25

\subsubsection{Possibility of a different syntactic interpretation: "Za vse boš plačal", v. 2}

\begin{tabular}{|l|l} 
Največ boš plačal za svoje rojstvo. & Most of all you will pay for your birth. ${ }^{26}$
\end{tabular}

(Literally: "The most you will pay for your birth.")

The role of the phrase "most of all" in initial position is ambiguous, since it would be most naturally interpreted as the conjunct meaning "above all", which normally occurs in this position. If it is understood as the object, its position is heavily marked. The other translation has the canonical English version: "You must pay the most for your birth." 


\subsection{The Slovene adverbial adjunct occupies a position which does not cor- respond to the position usual for this semantic type of adjunct in English}

Apart from the first example, where the adjunct is a preposed locative expression, the passages under discussion contain adjuncts of manner, which belong to the category of process adjuncts (Quirk et al. 1992, 482). These are usually placed in final position; if they are obligatory for the verb, no other position is likely at all (op. cit., 562). The passage containing a locative adjunct is restructured as an existential clause in one translation, whereas the manner adjuncts are all assigned other syntactic roles in one of the translations. Thus they occur as a premodifier in a noun phrase, as the agentive adjunct in a passive structure, and as a supplementive clause respectively.

\subsubsection{Existential clause: "Za prevali", v. 12}

Za prevali ni sledi. Beyond the mountain pass there is no trace. ${ }^{28}$

(Literally: "Beyond the mountain passes are no tracks.")

The alternative translation employs the same structure as the original, i.e. subject-predicator inversion accompanying the preposing of the adjunct: "Beyond the passes are no tracks." ${ }^{29}$ For a discussion, see 2.1.1.

\subsubsection{Premodifier in a noun phrase: "Za prevali", v. 8}

Za prevali se hitro poslavljajo

prijatelji, ljubimci, znanci.
Beyond the mountain pass bid speedy farewell friends, lovers, acquaintances. ${ }^{30}$

(Literally: "Beyond the mountain passes speedily bid farewell / friends, lovers, acquaintances.")

In Slovene, the pre-verbal position of the manner adjunct is the canonical one, since a deadjectival manner adverb has a well-nigh fixed position before the predicator (Toporišič 1967, 258), thus representing an exception to the principle of FSP-dominated word order. In English, on the other hand, this position would be uncommon. Therefore the translation quoted above re-creates the same order of ideas through transforming the adverb into an adjective, which can occur before the notion of "farewell" by functioning as a premodifier. The other translation employs the canonical word order: "Beyond the passes, friends and lovers, / acquaintances bid farewell fast." 31 


\subsubsection{Passivisation -> agentive adjunct role: "Tihi škrebetavec", vv. 4-9}

Belo kost, zakopano v pepelu,

struži š črnimi nogami,

nežnejšimi od puha,

tihi stružnik

z nečitljivim namenom

$\mathrm{v}$ pikčastih očeh.
Buried in ash, the white bone

Is planed by the black legs,

Gentler than thistledown,

Of the quiet planer,

With an unreadable intention

In its speckled eyes." ${ }^{\prime 2}$

(Literally: "The white bone, buried in ashes, / planes with its black legs, / gentler than thistledown, / the quiet planer / with an unreadable purpose / in its speckled eyes.")

In this case, the change of the syntactic role of the adjunct cannot be explained by any difficulties arising from its original position, since it is placed after the predicator in Slovene. The explanation is probably to be sought in an attempt to preserve the final position of the participant stružnik ("planer") while maintaining a coherent narrative: if the instrument adjunct "with (the/its) black legs" was to appear before the owner of the legs - the agent "planer" - has been mentioned, its reference would be unclear. The restructuring employed, on the other hand, creates a well-knit sentence.

The other translation employs the active voice: "Rubbing smooth a white bone / buried in ashes / with its black legs / softer than down / a silent grinding-tool / with inscrutable purpose / in its dots of eyes." ${ }^{3}$

\subsubsection{Supplementive clause: "Za prevali”, v. 7}

Samo gibi v zraku krožijo srebrno.

Only gestures in the air still circle, $\underline{\text { silver. }}{ }^{34}$

(Literally: "Only gestures in the air circle silverly.")

The final position of the Slovene manner adjunct is highly marked and emphatic, since a deadjectival manner adverb normally occurs before the predicator. In English, by contrast, the final position would be the most natural choice, but it is preserved in neither translation. In the version quoted above, the adverb is replaced by an adjective; the latter still realises an adverbial adjunct, but one which has a much more vague semantic connection with the rest of the sentence, namely a supplementive clause. This change is probably motivated by word choice, since the adverb "silverly" is rather unusual, particularly when used in reference to movement. 
The alternative translation, "Only the gestures circle silverly in the air," ${ }^{35}$ preserves the form and function of the adverb, as well as its position after the predicator. Nevertheless, its original placement at the very end is not re-created because the locative adjunct "in the air" has been moved to occupy this position. The movement of this adjunct from its pre-verbal position is in accordance with the usual English word order. Moreover, its placement after the manner adjunct is in keeping both with the end-weight principle (the "heavier" prepositional phrase being placed after the adverb) and the tendency of final adjuncts to follow the sequence "process - space".

\section{Conclusion}

The structures employed in the English translations of Slovene post-verbal subjects, preverbal objects, and adverbial adjuncts with the purpose of re-creating the original sequence of participants may be summarised as follows: Non-initial Slovene subjects display the widest range of possibilities. They may appear as the notional subjects of existential and presentational there-clauses, as agentive adjuncts in passive structures, objects (assigned this role by the use of epistemic converses), discontinuous noun phrases, appositive phrases, and supplementive clauses. Non-final Slovene objects, on the other hand, may be assigned the subject role by the use of passivisation or epistemic converses, or, less typically, even assume the role of adverbial adjuncts in passive structures. Attempts at preserving the original syntactic structure as well as word order may result in ill-formed structures, or at least in structures offering the possibility of a different syntactic interpretation. Adjuncts, finally, may be used in the framework of existential clauses, or rendered as other clause or even phrase elements. These changes are not always due to their original position in the clause, but also to stylistic considerations such as word choice. The diversity of the translations reflects the difficulty involved in maintaining a balance between the original text structure and the requirements of the target language.

\section{Bibliography}

Biggins, M., trans. 1988. Whiteness. In Vilenica 88, ed. V. Taufer, 235. [Ljubljana]: Društvo slovenskih pisateljev, Sežana: Zveza kulturnih organizacij.

- - -, trans. 1994. Snake Killers. In Prisoners of Freedom: Contemporary Slovenian Poetry, ed. A. Debeljak, 64-5. Santa Fe: Pedernal Press.

Davis, M. 1989. Aspects of Adverbial Placement in English and Slovene. München: Sagner.

Firbas, J. 1992. Functional Sentence Perspective in Written and Spoken Communication. Cambridge: Cambridge University Press.

Johnson Debeljak, E., trans. 1997. The Captive Wolf. In The Imagination of Terra Incognita: Slovenian Writing 1945-1995, ed. A. Debeljak, 195. Fredonia, New York: White Pine Press.

- - -, trans. 1997. The Crow. In The Imagination of Terra Incognita: Slovenian Writing 1945-1995, ed. A. Debeljak, 197-8. Fredonia, New York: White Pine Press.

- - -, trans. 1997. Great Black Bull. In The Imagination of Terra Incognita: Slovenian Writing 1945-1995, ed. A. Debeljak, $203-4$. Fredonia, New York: White Pine Press.

35 Perčič and Peet 1988. 
- - -, trans. 1997. White. In The Imagination of Terra Incognita: Slovenian Writing 1945-1995, ed. A. Debeljak, 201-2. Fredonia, New York: White Pine Press.

- - -, trans. 1997. You Must Pay for Everything. In Krokar, 52. Ljubljana: Edina.

- - -, trans. 2000. Beyond the Passes. In Ogenj v ustih (CD), by D. Zajc and J. Škof. Ljubljana: Študentska založba.

Kirkwood, H. W. 1970. Some Systemic Means of "Functional Sentence Perspective" in English and German. IRAL 8, no. 2 (May): $103-14$

Klinar, S. 1996. Prevajanje slovenskih predložnih prislovnih določil. In Prispevki k tehniki prevajanja iz slovenščine $v$ angleščino, ed. S. Klinar, 270-9. Radovljica: Didakta.

Kravanja, S., trans. 2000. Captive Wolf. In Scorpions, 39. Litterae Slovenicae 1/2000/XXXVIII/96. Ljubljana: Slovene Writers' Association.

- - -, trans. 2000. Raven. In Scorpions, 32-3. Litterae Slovenicae 1/2000/XXXVIII/96. Ljubljana: Slovene Writers' Association.

MacKinnon, A., trans. 1965. All the Birds. In Slovene Poets of To-day, 134-5. Ljubljana: Slovene Writers' Association.

- - -, trans. 1965. The King. In Slovene Poets of To-day, 136-7. Ljubljana: Slovene Writers' Association.

- - -, trans. 1980. The Silent Grindbeetle. In Panorama of Contemporary Slovene Literature, eds. C. Zlobec and H. Glušič, 41-2. Ljubljana: Slovene PEN Centre \& Slovene Writers' Association.

Perčič, T., and B. Peet, trans. 1988. Beyond the Mountain Pass the Eye of God Rots. Le livre slov ne XXVI/1988, nos. 1/2: 15-6.

- - -, trans. 1988. You Will Pay for Everything. Le livre slov ne XXVI/1988, nos. 1/2: 14.

Quirk, R., S. Greenbaum, G. Leech, and J. Svartvik. 1992. A Comprehensive Grammar of the English Language. London: Longman.

Taufer, V., and M. Scammell, trans. 1970. The Big Black Bull. In New Writing in Yugoslavia, ed. B. Johnson, 249. Harmondsworth: Penguin. = Le livre slov ne XX/1982, nos. 1/2: 53.

- - -, trans. 1970. The King. Modern Poetry in Translation 8: Slovenia (Yugoslavia): 14. = Le livre slov ne XX/1982, nos. 1/2: 51-2.

- - -, trans. 1970. Snake Killers. In New Writing in Yugoslavia, ed. B. Johnson, 246-7. Harmondsworth: Penguin. = Le livre slov ne XX/1982, nos. 1/2: 53-4.

- - -, trans. 1982. All the Birds. Le livre slov ne XX/1982, nos. 1/2: 54.

- - -, trans. 1997. The Chaferbug. In Krokar, 60. Ljubljana: Edina.

Toporišič, J. 1967. Besedni red v slovenskem knjižnem jeziku. Slavistična revija 15: 251-74.

- - - 2000. Slovenska slovnica. 4th ed. Maribor: Obzorja.

Zajc, D. 1990. Pesmi. Dane Zajc v petih knjigah. Ljubljana: Emonica.

- - -. 1998. Dol dol. Ljubljana: Nova revija. 